\title{
Lars Von Trier'in Antichrist Filminin Görsel ve Psikolojik Analizi
}

\author{
Tuğba Y1lmaz* \\ Burhan Y1lmaz** \\ *Çankaya Üniversitesi, Fen Edebiyat Fakültesi, Psikoloji Bölümü \\ **Çankırı Karatekin Üniversitesi, Güzel Sanatlar Fakültesi, Resim Bölümü
}

\begin{abstract}
Özet
Lars Von Trier'in 2009 yapımı Antichrist adlı filminde, çocuğunu kaybeden bir çiftin yaşamı konu edilmektedir. Çocuğunun ölümünden sonra yasa bürünen kadının psikolojisinin bozulmasıyla, filmdeki karakterler ve yaşamları üzerinden bir dizi tartışma su yüzüne çıkar. Kültürel cinsiyet rolleri, iktidar, bilgi, kadın doğası, doğa ve pagan kültür gibi kavram ve bilgiler, karakterlerin arasında gelişen gerilimli ilişkilerin etrafında konumlandırılmıştır. Kadının psikolojik rahatsızlığının ilerlemesi sonucu, terapist olan kocasıyla Eden denilen ormandaki kulübeye giderler. Orada gelişen süreç ile kadının korkularıyla yüzleşerek iyileşmesi umudu ortadan kalkar. Kadın çocuğunun kaybından doğan suçluluk duygusuna kapılır ve üzerinde çalıștığı pagan inanıșın etkisinde kalır. Bütün bu olaylar ustaca kotarılmıș olan dört bölümlük anlatımla sunulmuştur. Sanat tarihi ve resim sanatını işaret eden görüntü tercihiyle, Andrei Tarkovsky sinemasının özelliklerini açıkça barındıran filmin görselliği seçkin bir estetik anlayışla kurgulanmıştır. Filmde yönetmenin psikolojik anlamda birçok konuyu sembollerle işlediği dikkat çekmektedir. Örneğin terapötik ilişki bağlamında etik bir sorgulama karı koca ilişkisi üzerinden sunulmuştur. Filme hakim olan duygular senaryosunun içeriği doğrultusunda öfke, üzüntü ve korkudur. Yönetmenin yaşam öyküsü ile ilgili birçok ayrıntı barındıran bu filmin ele alınışında anneye duyulan öfkenin yansıtılması, kastrasyon kaygısı ile baş etmek için baba ile özdeşim kurma ve onun idealize edilmesi ve asal sahne fantezileri gibi noktalara değinilmiştir.
\end{abstract}

Anahtar sözcükler: yansıtma, öfke, kaygı, sanat, savunma mekanizmaları 


\section{Lars Von Trier'in Antichrist Filminin Görsel ve Psikolojik Analizi}

\section{Antichrist Filmi Hakkında Genel Bilgi}

Bu metinde ele alınan Antichrist filmi, Danimarkalı yönetmen Lars Von Trier'in 2009 yılında gösterime giren uzun metrajlı sinema filmidir. Film, psikolojik gerilim türünde sınıflandırılmaktadır fakat filmin bazı özellikleri izleyiciyi aşırı rahatsız edebilecek şok etkileri barındırdığından vahşet ve korku filmi kategorisine de girmektedir.

Türkiye'de 2010 yılında gösterime giren filmde, üç-dört yaşlarındaki çocuğu pencereden düşerek ölen bir çiftin kederli yaşantısı ve daha sonra başlarına gelen çarpıcı olaylar anlatılmaktadır. Filmde Charlotte Gainsbourg yas içindeki anneyi, Willem Dafoe ise eşini teselli etmeye ve tedavi etmeye çalışan babayı canlandırmaktadır. Çocuğunun ölümünden sonra kadının yas süreci bir tür psikolojik çöküntüye dönüşür. Adamın karısını içinde bulunduğu durumdan kurtarmak amacıyla Eden adını verdikleri ormandaki bir kulübeye götürmesiyle hikâyenin seyri değişmektedir.

Genel olarak, birkaç sahne dışında, sadece iki kişinin göründüğü filmin içerisinde gizlenmiş, olayların içeriğini veren bazı sayı ve isimlendirmeler de etkileyici bir kurguyla hikâyenin ilerleyişindeki sürprizleri ve değişimleri bütünlüğe kavuşturmaktadır. Diğer yandan yönetmen tarafından sinema tarihinin büyük ustalarından Rus yönetmen Andrei Tarkovsky’e adanmış olan filmde, görünen olayların ardında insan psikolojisi, kültürel cinsiyet rolleri, kültür doğa karşıtlığı gibi çeşitli kavramlara rastlamak ayrı bir heyecan olarak eklenebilmektedir. Film hakkındaki bu genel bilgiden sonra, yönetmen Lars von Trier'in geçmişine kısaca değinmek yerinde olacaktır.

\subsection{Yönetmen Lars Von Trier hakkında}

Antichrist filmi ile sinema sanatındaki kariyerini sağlamlaştıran Lars von Trier, alanındaki en tartışmalı isimlerden biridir. Trier, kimi eleştirmenlere göre bir dahi, kimilerine göre ise sıradan bir yönetmendir. Resim eğitimi de almış olan Trier, çocukluğundan itibaren film yapımıyla ilgilenmiş ve sinema eğitimi almıştır. Çocukluğunda nüdist bir anne-baba ile yetiştirilmiş olması, Trier'in sinemasındaki doğa ve beden bütünleşmesi konusunu ele alması, ahlaki sorgulamaları sert bir şekilde yapması ve filmlerindeki sınırları zorlayan yönlerin açıklanmasına katkıda bulunabilir.

Trier, 1995 yılında yayımladığı manifestosu ile Dogma 95 akımını kurarak film yapımındaki çizgisini netleştirmiştir. Hollywood filmlerindeki kalıpların dışında, belgesele yakın, özgün bir sinema dili geliştirmeyi hedefleyen yönetmen, Dogma akımıyla hareketli kamera kullanımı, yakın ve uzak çekim planlarının kullanımı gibi deneysel yönleri öne çıkan bir tarz geliştirmiştir. 1996 yılında tamamladığı Dalgaları Aşmak ve yapımı 2000 yılında gerçekleştirilen Karanlıkta Dans adlı filmleriyle Cannes Film Festivalinden ödüller alan 1956 doğumlu Danimarkalı yönetmen, kendine has tarzıyla her zaman adından söz ettirmiştir (Stevenson, 2005). 2003 yılında çektiği Dogville ve 2005'te tamamladığı Manderlay adlı filmler yönetmenin sinema dilinde sınırları zorlayan en önemli eserleri olarak bilinmektedir. Trier, yapımcı Peter Albaek Jensen ile Zentropa Film Şirketi’nin kurucusudur (www.imdb.com). 


\section{Antichrist Filminin Görsel Analizi}

Antichrist klasik bir filmden farklı işleyen olay örgüsü ve anlatımla oluşturulmuş bir filmdir. Klasik bir sinema türünde "ana olay örgüsünün (diegesis) temel özellikleri olarak şunlar görülür: örgü genellikle devamlılık esası gereğince tekil olarak sunulur” (Mencütekin, 2010). Antichrist filmi ise olay ve içerik açısından klasik sinema tanımının dışındadır. Dört bölümden oluşan Antichrist, postmodern anlatı olarak görülebilecek bir örgüyle işlenmiştir. Dört ayrı başlıkla belirlenmiş olan bu bölümler filmde sunulan hikâyenin bütününü dört aşama olarak izleyiciye aktarmayı hedeflemektedir. Yas, Acı, Umutsuzluk ve Üç Dilenci olarak ayrılan bölümler hikâyenin ilerleyişine göre sıralanmıştır.

Filmin başında yeşil zemine kırmızı renkle, elle yazılmış Antichrist yazısı görünür. Antichrist kelimesinin sonundaki ' $\mathrm{t}$ ' harfi kadın sembolü şeklinde yazılmıştır. İzleyiciye daha ilk saniyelerde sunulan bu veri, daha sonra anlamlanacak olan bir simgeleştirme olarak görülebilmektedir. Yeşil zemin olayların geçtiği doğayı, yazının kırmızı olması olayların içeriğindeki şiddeti ve son harfin kadın simgesi olarak çizilmesi, olayların içeriğindeki kadın, kadın doğası gibi konuları işaret etmektedir.

Filmin ilk sahnelerinde siyah beyaz ve yavaş çekim tercih edilmiştir. Filmin baş karakterleri olan erkek ve kadın sevişirken, hafif açık bırakılmış pencere görüntüsü ile sessize alınmış telefon görüntüsünün ardından yatağından çıkan küçük çocuk kadraja girer. Çocuk anne ve babasından habersizce odasından çıkıp, açık duran pencereye yönelir. Tam bu noktada pencereden içerde duran masanın üzerindeki üç küçük heykel dikkat çeker. Çocuk eliyle heykelleri iterek düşürür, pencereye çıkar ve pencereden dışarı düşer. Bu sahnede düşen heykellerle filmin içerisinde düğümlenen olayların işareti verilmiştir. Heykellerin kaidelerinde "yas, ac1, umutsuzluk" kelimeleri yazılıdır. Bunlar çocuğun düşüp ölmesinin ardından filmin bütün gidişatını belirleyen aşamalardır.

Filmin 'Yas' bölümünde ölen çocuğunun ardından yasa bürünen acılı ailenin durumuna odaklanılmaktadır. Kadın içinde bulunduğu durumda, çocuğunun ölümünden kendisinin sorumlu olduğunu, çocuğunu kurtarabileceğini, fakat yeterince dikkatli olmadığı için bu durumu önleyemediğini düşünmektedir. Bu nedenle daha fazla acı duymaktadır. Ağır bir şekilde suçluluk duygusuna kapılmıştır. Terapist olduğu anlaşılan erkek, eşinin acısını hafifletmek için onunla diyalog kurar ve bu diyalog ailenin kısa zaman önceki geçmişine, kadının korkularına ve ihmallere kadar gider. Bu arada adam, teselli etmenin ötesinde eşine terapi yapmaya başlamıştır. Adam eşini içinde bulunduğu durumdan kurtarmak için, onu, korkularının kaynağı olduğunu düşündüğü, ormanın içerisindeki kulübeye götürmeye karar verir. Bu ormanın adı 'Eden' yani cennettir. Bu isimlendirme ile yönetmen izleyiciye kadını Havva, adamı da Âdem olarak sunmakta; onların sevişmesi sırasında çocuğun düşerek ölümünü ise ilk günahla ilişkilendirmektedir. Belirtmek gerekir ki, adam ve kadının filmde isimleri yoktur. Filmdeki karakterler 'Erkek ve Kadın' olarak geçmektedir (Antichrist, n.d.).

Filmde yönetmen, bazı farklı çekim ve kamera hareketleri aracılığıyla ayrıntıları, olayın yaşanışını ve etkilerini izleyiciye bir 'gerçeklik' olarak hissettirmek ister. Kadının acı duyduğu, ağladığı ve zaman zaman kriz geçirdiği anlar kamera hareketleriyle desteklenerek anlatılmaktadır. Kamera geniş açıdan dar açıya geçip ayrıntılara odaklanarak hikâyedeki durumların anlatım olanağını genişletir. Mesela kadının içinde bulunduğu psikolojik yıkımın baş edilmez hale geldiği anların görüntüsü, kameranın kadının boğazındaki atardamarın hareketine, gözbebeklerinin ayrıntısına inerek mikro çekimlerle izleyiciye doğrudan aktarılmıştır. Filmi özel kılan noktalardan biri de şudur ki, bazen görüntülerdeki değişim kadının gözünden dünyanın görünüşünü de vermektedir. Böylece yönetmen, izleyiciye kadının psikolojik durumunu etkili bir şekilde 
aktarmaktadır. Bu sahnelerden biri de kadın ve adam trende giderlerken, pencereden akan doğa görüntüsü içerisinde birkaç kez belirip kaybolan korkunç surat ve figürlerdir. Bir başka sahnedeki orman görüntüsünde beliren aşırı hareketlilik kadının içinde bulunduğu psikoz halini izleyiciye hissettirmek için ustalıkla kurgulanmıştır.

Sonra çift, adamın sorgulamalarıyla kadının psikolojik sorunlarının kökeni ve korkularının kaynağı olarak belirledikleri Eden' a gelirler. Eden, filmin arka planını oluşturan doğanın (mekânın) adıdır. Eden'daki kulübeye doğru giderlerken kadın sık sık ilerlemekte zorlanır, duraklamak ve dinlenmek zorunda kalır. Filmde bu şekilde beden ve mekân ilişkisindeki aksamaların psikolojik rahatsızlıklara bağlı bir olgu olarak verilişi, postmodern sinema türünde görülen ve David Harvey'in belirtmiş olduğu zaman-mekân sıkışması düşüncesine denk gelmektedir (Harvey, 2010). Kadının ormanın içindeki patikada köprüden geçemediği sahne, daha sonra yere basamadığı sahnelere bakılırsa arızalanmış bir benliğin mekânda sınırlanışı ve bedenin hareketinin engellendiği görülür.

Bir başka sahnede, duraklamalardan birinde adam eğrelti otlarının ve çalılıkların arasındaki bir kıpırtıya yakından bakar. Burada bir ceylan görünür. Ürküp kaçan ceylanın hala arkasından ölü doğmuş yavrusu sallanmaktadır. Bu sahne daha önceden ölen çocuğu ve anneyi anımsatır. Filmde hayvanlar ve olaylarla ilgili başka bağlantılar da vardır. Kadının gördüğü bir olay bütün acısını yeniden ortaya çıkarır. Bir ağacın yüksek bir noktasındaki yuvadan bir kuş yavrusu düşer. Daha yarı canlıyken bir kartal gelip yavruyu kapıp parçalar ve yer. Kadın bunu gördükten sonra çok olumsuz bir hisse kapılır. Çünkü yuvadan düşen küçük kuş yavrusu, kadının kendi yavrusunun kendi yuvasından (evinden) düşerek ölmesine benzetilmiştir. Diğer yandan yine adamın çalılıklar arasında gördüğü yaralı görünen bir çakal, bir anda dile gelir ve "kaos hükmeder" diyerek izleyiciyi şok eder. Duyguların gerçekçi bir sunumunu yapmaya özen gösteren filmdeki bu sahne, adamın gördüğü konuşan çakal, gerçekliğin ve kurgunun karıştığı nokta olarak, izleyicinin de ortak olduğu bir halüsinasyona dönüşür.

İlerleyen kısımlarda kadın karakterin durumu iyileşmek yerine gittikçe daha kötü bir hal alır. Bu sırada adam kadının çalıştığı fakat bitiremediği teziyle ilgili dokümanları, notları ve resimleri bulup inceler. Pagan inanışlar, kadın, doğa ve cadılıkla suçlanarak öldürülen kadınlarla ilgili olduğu anlaşılan bu belgeler, filmin isminin anlaşılmasını sağlamaktadır. Ayrıca ölen çocuğunun fotoğraflarında, çocuğun ayakkabısının ters giydirilmiş olması ve otopsi raporunda çocuğun ayaklarında belirlenen anormallik de adam tarafından fark edilmiştir. Bu konuyu aralarında tartışırlar. Kadın, araştırdığı konuya kendini kaptırmış ve pagan bir inanış içerisine girmiştir. Kadın yıldızların bir konuma gelmesiyle üç dilenci diye adlandırılan geyik, çakal ve karganın bir araya geleceğini ve bu durumda insanlardan bir kurban seçilerek öldürülmesi gerektiğine inanmaktadır. Filmde bu üç hayvanın Eden'daki kulübeye geldiği görülür ve kadın adamı kurban etmek için bayıltır. Adam bir şekilde kurtulur ve kadını öldürmek zorunda kalır.

\subsection{Antichrist Filminin Kültür-Sanat-Sinema Bağlamında Değerlendirilmesi}

Film, kültür ve sanat tarihi açısından ele alındığında, pagan inanış kültürüne ait mitolojik semboller, cadılıkla ilgili olayları gösteren gravürler ve Rönesans ustalarından ressam Hieronmish Bosh'un resimlerini andıran sahnelerdeki resimsel görüntüler dikkat çekmektedir. Filmin son sahnelerinde ormanın içerisinde yürüyerek geçen adamın arka planında yerde yatan çıplak kadın figürleri belirir. Hepsinin yeraltında yattığı ve ayrı bir görüntü katmanında olduğu anlaşılan bu figürler doğrudan resim sanatı tarihindeki figür resimlerinden alınmış gibidir. Bu görüntüler yönetmenin sinema öğrenimine başlamadan önce resim sanatıyla ilgilenmiş olmasıyla ilişkili olarak da yorumlanabilir.

Antichrist sinema olarak farklılığını, olay örgüsünün dizilişinde ve hikayenin görsel 
anlamdaki kuruluşunda ortaya koymaktadır. Genel olarak sahne sanatlarında ve sinemada izleyicinin rahatsız edilmemesi gibi nedenlerle bazı şiddet içeren olaylar ve anlar gizlenir, izleyiciye sadece olayın olduğu bilgisi verilir. Bu Klasik Yunan tragedyalarından beri süregelen bir anlatım yöntemidir. Tragedyada ölüm ve şiddet sahneleri izleyiciye gösterilmez, olayın ardından verilen sahnelerle bir bilgi olarak sunulur (Akbal Süalp, 2004). Lars Von Trier ise Antichrist'te pornografiye varan açıklıkla şiddet ve vahşet öğelerini izleyicinin gözünün önünde sergilemektedir. Yönetmenin bu tavrı sinema sanatındaki bu klasik anlatımı özellikle reddettiği şeklinde yorumlanabilir.

İzleyicinin seyredemediği bu şiddet görüntülerine örnek vermek gerekirse, kadının adamın cinsel organına vurarak bayılttığı sahne; adamın bacağını burguyla delerek çark taktığı sahne; kadının her şeyin sorumlusu olarak gördüğü zevkin kaynă̆ını, kendi klitorisini makasla kestiği sahnelerde görüntü hiç aksamadan, kamera herhangi bir şekilde çekilmeden doğrudan olan biteni vermektedir. $\mathrm{Bu}$ görüntülerde izleyicinin bakışını kesip parçalayan aşırı gerçekçi bir yön vardır. $\mathrm{Bu}$ görüntüler Jacques Ranciere'nin görüntülerin niteliklerini tartıştı̆ğ “katlanılmaz görüntü” tanımına denk düşmektedir (Ranciere, 2010). İzleyenin bakışını değiştiren, gözünü kapattıran ve davranışını sekteye uğratan bu katlanılmaz görüntüler, Lars Von Trier'in kendi deyimiyle, izleyicinin ayakkabısına giren taşlardır (Stevenson, 2005).

Lars von Trier doğaya bakışı yönettiği görüntülerde (Tarkovsky’i andığı nokta bu kesitlerdedir) yönetmenliği bırakıp adeta ressamlığa soyunmuştur, çünkü görüntüler bir teknik görüntünün dolayımından kurtulmuş el üretimi bir dokunun görünümüne kavuşturulmuştur. $\mathrm{Bu}$ görüntü tercihinin düşünsel altyapısını Walter Benjamin'in (2004) kameraman ve ressamı konuya yaklaşım biçimi bakımından değerlendirdiği düşüncelerinde temellendirmek olasıdır. Benjamin, kameramanı hastasını ameliyat eden cerraha, ressamı ise hastasına belli bir mesafeden yaklaşan şifacıya benzetmektedir. Trier de filmin çekimlerinde aldığı kararlar, seçtiği kadrajlar ve filtrelerle bazen kameraman- cerrah, bazen de ressam-şifacı olarak karşımıza çıkmaktadır. Kameranın uzak çekimlerdeki aşırı mesafeli tutumu ve yakın çekimlerdeki objelerin ve figürlerin iyice içine, tenine, dokusuna girdiği görüntülerin kurgusunda, makro ve mikro çekimlerdeki geçişlerde bu cerrah ve şifacı benzetmesini açıklayan tavırlar görülebilir. Mesela durgun bir orman görüntüsünden yakın çekim bir ağaç görüntüsüne geçişlerde bir cerrah müdahalesi keşfedilebilirken; film karakterlerinin doğa içinde göründükleri sahnelerdeki dokunma duygusunu da içeren görüntülerde ressam-şifacının etkisi keşfedilebilir. Kadın ve adamın ağacın altında köklerin arasında birleştiği sahneye bakılırsa, sanat tarihinden çıkıp gelmiş birçok "el görüntüsünün" topraktan fişkırıp geldiği görülür. Burada beliren eller resim sanatı tarihinde doğa ve figür (kadın modelleri) resimlerindeki çeşitli noktaları çağrıştıran görünümler olarak verilmiștir. Bu el figürlerinin ağacın köklerini tutması resimsel bir dokunma türüdür. Benjamin'in (2004) bahsettiği büyüsellik ise zaten doğanın - büyük tapınağın- kucağında durmaktadır.

Trier, Antichrist filminde doğaya hem anlam hem de görüntü olarak Tarkovsky tarzında yaklaşmıştır. Tarkovsky'nin doğaya çevrilen kadrajı, özellikle Ayna (1975), Stalker (1979) ve Nostalji (1983) adlı filmlerindeki manzarayı öne çıkarır. Tarkovsky, manzaranın "en ufak bir kesinlik taşımadığı için kavramsallaştırılamayanı ifade etmeye yönelik kavramsal bir araç olduğuna dikkat çeker" (Botz-Bornstein, 2011). Trier de tıpkı Tarkovsky gibi Antichrist'te belirsizleşen çizgileri, devinim içindeki ormanı, ağaçları, çalıları ve kökleri çerçeveye alır ve izleyiciye bir imge olarak sunar.

Kadın bedenleriyle bütünleşmiş doğa görüntüsü, filmdeki hikâyenin içeriğini ele verir. Filmde kadın doğasının şeytan ile ilişkili olduğu vurgusu, Camille Paglia'nın 'kitonyen' kavramıyla açıklanabilir. Kitonyen, yeraltına ait, doğanın dişil gücünü ifade eden kavramdır (Paglia, 2004). Filmde geçen diyaloglarda bahsedilen şeytanla ilişkili olan "kız kardeşler", doğa içerisinde beliren kadın figürleri kitonyen kavramına işaret etmektedir. Ölüm, yas, doğa ve cinsel 
kimliklerin yanında filmin kişisel duygulara odaklandığı bütün görüntüler sadece iki kişiyle ilgilidir, bunun karşısında, başlangıçtaki mezarlık sahnesinde görülen kalabalık ve filmin sonunda kadının ölümünden sonra ormanda bir tür hayal gibi görünen kadınlar, ölümün toplumsal yanını vurgulamaktadir (Buck-Morss, 2010).

\section{Antichrist Filminin Psikolojik Analizi}

\subsection{Etik}

Genel Etik kurallardan olan yararlı olmak ve zarar vermemek başlığı altında dikkati çeken en önemli etik ilkelerden biri psikologların çoklu ilişkiler kurmamasıdır. Diğer bir deyişle, psikolog danışanı ile olan ilişkisindeki profesyonel rolüne ek olarak başka bir ilişki içine girmemelidir. Filmlerinde etik yargılamayı sıklıkla konu edinen Lars von Trier'in Antichrist filminde görüldüğü üzere bebekleri Nic'in kaybından sonra kadın ağır bir yas sürecine girmiş ve hastanede bir ay tedavi görmüştür. Bu tedaviyi uygun bulmayan erkek, kadının tedavi sağlanması için kendisinin ona psikoterapi vermesi gerektiğini düşünür. Psikoterapist olarak görev yapan erkek karakter terapist becerilerini kendi eşinin tedavisinde etkin bir şekilde kullanabileceğini düşünmüştür. Etik kurallara göre bu çoklu ilişki kurmak anlamına gelmektedir. Benzer şekilde, TPD’nin "Psikoterapi ile ilgili etik kurallar" başlığı altında belirttiği üzere psikologlar hizmet verdiği ya da vermiş olduğu danışanlarla, danışanların yakınları ve akrabaları ile duygusal yahut cinsel ilişki kuramaz (Türk Psikologlar Derneği, 2004). Erkek karakterin eşi ile terapiye başladığında onunla cinsel olarak birlikte olmayacağını söylemiştir. Ancak bebeğinin ölümü sonrasında travmatize olan, kadınlığını ve analığını sorgulayan kadının en acil ihtiyacının eşinden psikoterapi almaktan ziyade sosyal destek almak, yas sürecinin ve acının paylaşılması olduğu görülmektedir. Bu nedenle erkek karakter karısına verdiği bu sözü tutamaz ve terapi sürecindeyken cinsel birliktelik yaşamaya devam ederler. Terapist profesyonel kimliğini "karı-koca" ilişkisini engelleyerek devam ettireceğini planlamış ancak bunda başarılı olamamıştır. $\mathrm{Bu}$ terapist-danışan arasındaki ilişkinin profesyonel bir ilişkiden çıkmasına neden olarak, beklenen terapi yararlarının oluşmamasını; aksine, yaralayıcı deneyimlerin gerçekleşmesine neden olmuştur.

Danışanın terapisti ile kurduğu ilişkisine geçmişinden başka bir kişi ile kurduğu ilişkiyi benzetmesi durumuna aktarım; terapistin danışanı ile olan ilişkisinde kendi geçmişinde bir kişi ile kurduğu ilişkisini benzetmesi ise karşı aktarım olarak değerlendirilir (Gabbard, 2004). Terapistin danışanı ile kuracağı profesyonel rol dışında kalan diğer ilişki biçimleri, terapiye konu edilen aktarım ve karşı aktarımı bozar niteliktedir. Bu nedenle çoklu ilişkinin oluştuğu terapötik ilişkilerde aktarım ve karşı aktarım, terapi dışındaki sürelerde de görüşülmesinden ötürü terapiye özgü olan niteliğini kaybeder. Danışanın terapötik olarak ele alınması için kullanılacak olan bu iki kavram, terapi dışında kurulan ilişki yüzünden bozulmuş olur ve bu da terapinin olumlu sonuçlar vermesini engeller.

Filmde erkek, eşinin terapisti olmaya çalışıp kadının korkularını yenmesi için davranışçı bir metod olan kognitif yeniden yapılandırma tekniğini (Gençöz, 2001) kullanmaya karar verir. Teknik, düşüncelerin duyguları açığa çıkardığı varsayımının ele alınması, danışanın durumlara gerçekçi bakış açısı getirmesi için çalışılması, kaygı/korkuya neden olan varsayımların belirlenmesi ve bu varsayımların yeniden değerlendirilmesini içerir (Gençöz, 2001). Bu aşamada danışana özgü kaygı uyandıran durumların hiyerarşik olarak belirlenmesi tekniği kullanılabilir. Ancak filmde erkek bu tekniği gerektiği gibi kullanamaz. Çünkü karısı ile kurduğunu sandığı terapötik ilişki, varolan karı-koca ilişkisinin niteliği yüzünden terapiyi destekleyen işlevsel düzeye çıkamaz. Nitekim erkek, hiyerarşide kadının en hafif düzeyde korktuğu yer ile çalışmak yerine kadının en çok korktuğu yer olan Eden ile çalışmaya başlar. Bu durumun doğru sonuçlar 
doğurmayacağını gösterircesine, Lars von Trier'in Eden'a gittikten sonra filmde gergin ve şok edici sahneleri daha yoğun kullandığı görülür.

\section{Duygular}

Altı temel duygu olan öfke, üzüntü, iğrenme, mutluluk, korku ve şaşkınlık (Power \& Dalgleish, 2008) incelendiğinde bu duyguların filmdeki karakterler tarafından yaşanmış ve aynı şekilde de izleyiciye aksettirilmiştir. Filmde kadın karakterin bebeğinin cenazesinde kendini kaybettiği, 1 ay süre ile hastanede tedavi görecek denli ağır üzüntü ve depresif duygulanım yaşadığg görülmektedir. Üzüntünün bir kişiye kendi ölümlülügüüü ya da kişinin sevdiği birinin ölümünü hatırlatıldığında hissedilen temel bir duygu olarak kabul edildiğinde (Power \& Dalgleish, 2008) kadının yaşadığı üzüntü duygusunun bebeğin kaybı neticesinde olması izleyiciye anlamlı ve olaya karşı verilen doğal bir tepki gibi gelir. Ancak kadının hastanede 1 ay bilinci kapalı şekilde tedavi görmesi olaya verilen aşırı bir yas tepkisidir ve bu tepkiyi yalnızca üzüntü ile açılamak yetersiz kalır.

Çocuklar ve yetişkinlerde üzüntü ve yasın önemli olması bağlanma teorisi ile açıklanabilir (Bowlby, 1988). Çocuklar kendilerinin bakımını üstlenen kişiye (bakıcısına/ annesine) bir tür bağlanma geliştirirler (Bowlby, 1988). Ainsworth (1978) bağlanmayı Yabancı Durum Testi ile çalışmıştır. Ainsworth (1978) çalışmasında bakıcı ve çocuğu bir laboratura almıştır. Çocukların bakıcıları gözetiminde oyun oynadıkları sırada yabancı bir kişi odaya girmiştir. Yabancı kişi çocukla ilgilenmiştir ve böylece çocuğun bakıcısından ilk kez ayrılması sağlanmıştır. Ardından, bakıcısı çocuğu rahatlatmıştır ve yabancı odadan çıkmıştır. Böylece ayrılık sonrası ilk birleşme gerçekleşir. İkinci ayrılık bakıcının odadan çıkması ile gerçekleşmiştir. Odaya yabancı kişi tekrar girer ve çocukla ilgilenir. Son olarak ikinci birleşme çocuğun bakıcısı odaya girmesi ile olur ve bakıcısı çocuğu sakinleştirir. Bu esnada yabancı kişi odadan çıkmış olur. Araştırmacılar çocukların yalnız kaldığında ve bakıcısı ile buluştuğunda verdiği tepkileri incelemiştir. Buna göre, bazı çocuklar, bakıcılarının geri dönüşü üzerine mutlu olmuşlardır. Bunlar güvenli bağlanan çocuklardır. Bazı çocuklar ise bakıcılarından ayrılmalarını ağlarayarak protesto etmiş ve bu duruma ümitsizlik göstermiştir. Bakıcıları dönünce onlara koşmuş ancak bakıcılarına vurma gibi öfke belirtileri göstermiştir. Bu tip çocuklar kaygılı bağlanmaya sahiptir. Bazı tip çocukların bakıcılarından ayrıldıktan sonra ağlamadığı görülmüştür. Bu tip çocuklar ise bakıcıları geri döndüğünde onlardan kaçınır ve bakıcılarına öfkeli görünürler. Bu tür bağlanma ise kaçıngan bağlanmadır.

Bowlby, kaygılı ve kaçıngan bağlanma gösteren çocukların, bakıcılarının kaybı üzerine hissettikleri olumsuz duyguları savunucu bir şekilde dışladıkları ya da engelledikleri için oluştuğunu belirtmiştir (1980). Olumsuz duygulanım üzerine kaygılanmak ya da bu duygulardan kaçınmak, olumsuz duygulanımın işlenmesinin süresini uzatabilir. Bu durum, kaçıngan ve kaygılı bağlanması olan yetişkinlerin olağan üzüntü ve yas sürecinin uzaması ve yasa karşı verilen anormal tepkilerin doğasının uzun sürmesini açıklayabilir (Power \& Dalgleish, 2008). Bağlanma figürünün kaybına karşı verilen aşırı yas tepkisinin açıklanması için ayrı bir görüş ise bağlanma figürünün gerektirdiği ortak amaçların, rollerin ve planların kaybıdır. Bağlanma figürünün kaybı ile bu kişiyle ilişkilendirilmiş değerlerin kaybı da söz konusu olur (Power \& Dalgleish, 2008). Örneğin çocuğunun iyi okullarda okuyup kendisini başarılı bir anne olarak temsil etmesini bekleyen bir kadın; çocuğunu kaybetmesi ile çocuğuna atfettiği değeri ve beklentiyi de kaybetmiş olur. Kendilik değerini anneliği üzerine kuran bu kadın, anneliğinin çocuğunun kaybı ile sona ermesinin verdiği üzüntüyü de yaşayabilir.

$\mathrm{Bu}$ açıdan filmdeki kadın karakterin, olumsuz duygularını savunmacı bir şekilde dışladığı ve olumsuz duygularını engellediği düşünülebilir. Kadının, çocukluğunda annesi tarafından olduğu 
şekilde kabul edilmediği; olumlu ve olumsuz duygularının bir bütün olarak kabul görmemesi nedeni ile kendisinin de bu duyguları içselleştiremediği ve kaygılı bir bağlanma geliştirmiş olduğu düşünülebilir. Film açılışının eşlerin cinsel ilişki yaşarken sahnelendirilmesi ve filmde kadın tarafından başlatılan cinsel ilişkileri içeren sahnelerin sayısının çokluğu, kadın karakterin kadınlık, annelik ve üreme rollerine verdiği önemi gösterebilir. Bebeğinin kaybının, kadının önem verdiği rollerinin kaybını ve bu rollerde başarısız olduğunu temsil etmesi de kadını aşırı yas tepkisi vermeye yöneltmiş olabilir.

Üzüntü duygusunun diğer temel duygularla görülmesi sık görülen bir durumdur. Örneğin üzüntü ve öfke duygularının eş zamanlı yaşanması yasta patolojik durumların oluşmasını açıklayabilir (Power \& Dalgleish, 2008). Filmin ikinci yarısında, kadın karakterin, bebeğinin pencereye tırmanıp düşmeden önce onu gördüğü, ancak cinsel ilişkiyi sürdürdüğü sahne görülmektedir. Kadın filmin sonunda bebeğinin yatağından kalkıp yürümeye başladığını bildiğini söyler ve bebeğinin ölümünü engelleyebilecek olduğunu itiraf eder. Bu ifadesinden, kadının bebeğin ölümü için kendini suçladığı ve suçluluğunu kendine yönelmiş bir öfke ile ifade ettiği görülür. Bu nedenle ki kadın, filmin son sahnelerinde, kendi cinsel hazzı nedeni ile bebeğinin ölümünü engelleyemediğini düşünerek öfkelenir. Bebeğin ölümü için kendi cinselliğini suçlu bulması ve kendine yönelik olan öfkesi ile de klitorisini keser. Bu kadının kendi kendisini hadım etmesi anlamına gelmektedir. Kadın, öfkesini cinsel ilişkinin ikili bir eylem olması nedeni ile de erkek karaktere de yönlendirir. Erkeği, bacağını burgu ile delerek bir çark geçirmek sureti ile cezalandırır. Böylece erkeğin ayağını bağlar (ayakbağı) ve hareket etmesini engeller. Kadının bu türlü bir ceza yöntemi seçmesi çok sembolik bir anlam taşımaktadır. Burgunun penisi, çarkın da kadın cinsel organını temsil ettiği düşünüldügünde, bu şekildeki cezalandırmanın cinsel ilişkiyi temsil ettiği düşünülmüştür. Diğer bir deyişle, kadın karakter cinsel ilişkiyi sürdüren erkek yüzünden bebeğini kurtaramadığını düşünmüştür. Bunu kendisine bir ayak bağı olarak görmüş olabilir. Bu nedenle kadın erkeği cezalandırırken ona bir ayakbağı hazırlamıştır. Yani kadın erkeğin ayağını hareket edemeyeceği şekilde burgu delmiş ve çarkı geçirmiştir. Bu bilgiler kadının yas sürecindeki üzüntüsü ile eş zamanlı olarak kendine olan öfkesini yaşamasının kendine ve diğerlerine zarar veren patolojik örüntüsü üzerindeki etkisini açıklayabilir.

Eşinin bu halini gören erkek karakter ise tedaviyi kendisi üstlenerek bir tür telafi mekanizmasına girişmiştir. Kadın geçen sene Eden'a oğlu ile gelip tezi üzerinde çalıştığı zaman eşinin kendisi ve çocuğu ile ilgilenmediğine dikkat çeker ve erkeği onları yalnız bırakmış olmakla suçlar. Erkek de bu durumu başarısız bir baba olmak olarak değerlendirir ve bunu kontrol edebilecek olduğunun farkındadır. Suçluluğun içten gelen ve kontrol edilebilen başarısızlıklar sonucunda hissedilen (Power \& Dalgleish, 2008) ancak tolere edilmesi güç bir duygu olmas1, erkeğin bu duygu ile olanları telafi etmek yolu ile baş etmeye yönlendirir. Buradan hareketle erkek, karısının tedavisinde kendi yardımının hastane yardımından daha etkili olabileceğini düşünmüş olabilir.

\section{Asal sahne}

Asal sahne (primal scene) çocukların anne ve babanın cinsel ilişkilerini anlamasını ya da görmesini ifade eder. Çocuk bu sahneyi görür ve şiddet ile ilişkili bulur (Wolff, 1950) Psikanalitik kurama göre ödipal süreci yaşayan çocuk annesinin babası ile birlikte olduğunu anladığında yoğun bir kaygı yaşar. İlişkiyi durdurması durumunda da babadan gelecek cezalandırma ile kastrasyon kaygısını yaşayacağını bilir. Bu nedenlerle çocuk anne ve babasının odada ne yaptıkları hakkında düşünür, içeride olan biteni anlamlandırmak için bir şey bulur ve bulduğunu kendisi ile ilişkilendirebilir. Bu yol ile hissettiği kaygı duygusu ile başa çıkabilir.

Lars von Trier'in bu filminin afişinde, filmin açılış ve birçok sahnesinde kadın ve erkek 
diğer bir deyişle anne ve babanın cinsel ilişkilerini açıkça göstererek ele alması, asal sahneyle ilgili olan yoğun fantezileri ile ilişkilendirilebilir. Bu açıdan Lars von Trier’in geçmişinde halledemediği ve kendisinde öfke ve kaygı uyandıran konuları filmlerinde abartılı düzeylerde işlediği düşünülmüştür. Yönetmen, film boyunca anne ve babaya doyum verici bir cinsel ilişki firsatı tanımamıştır. Buna ek olarak, karakterleri cinsellikleri yüzünden bebeklerinin ölümüne neden olmamaları ile cezalandırır gibi görünmektedir. Bu bilgiler ışı̆̆ında yönetmenin kendi anne babasının cinselliği üzerindeki fantezilerinde kendine biçtiği role dikkat çekilebilir. Lars von Trier'in kastrasyon kaygısı ile engelleyemediği ebeveyn cinselliğini, filmlerindeki karakterler üzerinden sembolik düzeyde halletmeye çalıştığı düşünülmektedir.

\section{Yönetmen ve Savunma Mekanizmaları}

Yönetmenin savunma mekanizmaları iki başlıkla ele alınmaktadır. Bunlardan ilki yönetmenin annesine duyduğu öfkeyi kadın oyuncuya (Charlotte Gainsbourg) özdeşim kurarak yansıtmasıdır. Yaşam öyküsü incelendiğinde, Lars von Trier'in annesinin ölmeden önce Trier'e babasının biyolojik babası olmadığını söylemesi yönetmeni travmatize etmiş olabilir. Annesi Lars von Trier'e babasının eski işyerindeki patronu olduğunu itiraf etmiştir. Ancak yaşam öyküsüne bakıldığında annesinin Trier'e bu bilgiyi verdikten sonra öldüğü ve çocuğunun ne hissettiğini hiç konuşmadığı anlaşılmaktadır. Bu gerçekliğin kendisinden yıllardır saklanmış olması ve babası bildiği kişinin biyolojik babası olmadığını öğrenmesi Trier' in kendisini aldatılmış hissetmesine neden olmuş olabilir. Bu durum tıpkı Bowlby'in (1988) yaptığı çalışmaya benzer. Annesinin kaybının ve terk edilmişliğin verdiği üzüntü, Trier'in kendisini aldatılmış hissetmesine neden olmuş olabilir. Trier, annesine karşı duyduğu öfkeyi annesiyle hesaplaşamadığı için (unfinished business) içe atma mekanizmasıyla geliştirmiş olabilir. Ancak bu savunma mekanizması yansıtma özellikleri de kazanmış, bu sebeple filmdeki anne rolünü üstlenen kadına korkutucu özellikler atfetmiş ve şeytanilikle eşleştirmiştir. Filmde kadın çocuğunun ölümüne neden olduğuna kendini inandırmış ve bu nedenle kadının rahatsızlığı prognozu gittikçe kötüleşmiştir. Ayrıca oyuncu da rolünü içselleştirerek anılan psikolojik süreci çok iyi aktarmıştır. Buradaki aktarım yönetmenin yansıtma, içe atma ve özdeşleştirme savunma mekanizmalarından ileri gelmektedir. Bu yüzden yansıtmalı özdeşim olarak değerlendirilebilir (McWilliams, 2010). Yönetmen bu savunma mekanizmasını çok başarılı şekilde kullanmış ve seyirciyi de kendi tarafına çekmiştir. Bunun kanıtı da seyircinin Charlotte Gainsbourg'un oynadığı rolden ziyade kendisinden korkmaya ve nefret duymaya başlamasıdır. Şöyle ki, Gainsbourg’un oynadığı diğer filmlerde de seyirci farklı rollerde olmasına rağmen oyuncunun kendisine nefret duymuştur (B. Yılmaz ve K. Yılmaz, kişisel iletişim, 15 Aralık 2013).

Savunma mekanizması konusunda dikkat çeken ikinci örnek Trier'in filmde sanat öğelerini sıklıkla kullanması ve filmini ünlü Rus yönetmen Tarkovsky’e atfetmesidir. Böylece, filmin sanatsal içeriği ve elitist yönü Trier'in biyolojik babasının sanatla ilişkili olduğunu öğrenmesiyle ilgili olabilir. Çünkü annesi Trier'e, biyolojik babasını sanatsal bir çevrede yetişmiş olduğu için seçtiğini itiraf etmiştir (Stevenson, 2005). Trier, asla görmediği babasıyla ilgili duygularını sinema alanındaki elitist ve sanatsal tutumuyla sinemanın babası olarak bilinen Tarkovsky'e yansıtmış olduğu düşünülmüştür. Trier, aynı Tarkovsky gibi filminde resim sanatına fazlaca atıf göstermiş ve Tarkovsky'nin filmlerinde kullandığı ögelerden yararlanmıştır. Bunlara ek olarak, Trier'in filmini Tarkovsky’e atfetmesi de onu idealize ettiğini gösterir niteliktedir. Böylece Trier, hiç tanımadığ1 babasını Tarkovsky'e yansıtmıştır. Yönetmen, Tarkovksy ile özdeşim kurarak ve onu idealize ederek biyolojik babası ile tanışma yoluna gitmiştir. Ödipal süreçlerle ele alındığında Trier'in, babasının sanatsal özellikleri ile özdeşim kurarak ve bu özellikleri idealize ederek anneye ulaşmaya çalıştığı şeklinde bir yorum getirilebilir. Ancak hayatta olmayan biri olan Tarkovsky ile 
idealizasyon kuran Trier'in kastrasyon kaygısını gerçek anlamda halledemediği düşünülmüştür. Bu da Trier'in kaygı sorunları yaşaması ve birkaç farklı fobisinin olmasını açıklayabilir (Stevenson, 2005).

\section{Sonuç}

Konusu, senaryosu, görüntüleri ve içerdiği kültürel, psikolojik, sanatsal kodların aktarımı açısından başarılı bir film olarak değerlendirilen Antichrist, elit bir sinema izleyicisini hedef seçmiş olduğunu belirtmek gerekmektedir. Filmde görselliğin ve olayların akışının kurgulanışındaki paralellik izleyiciye kuramsal bir altyapının işaretini vermektedir. Yönetmen Trier'in özellikle seçtiği bu durum, yönetmenin diğer filmlerindeki tarzı ile örtüşmektedir. Filmin bir dizi olumlu ve olumsuz görülecek önermeleri genel olarak yaygın kültürün eleştirisi başlığ 1 altında toplanabilir. Trier, bu önermeleri aktarmak için zıt özelliklerdeki bireyler arasındaki diyalogların ve olayların ayrıntılarını işlemiştir. Yönetmenin ayrıntılara verdiği kritik önem, film içerisindeki ayrıntıların olayların gidişatını önceden işaret etmesinde görülebilmektedir. Filmdeki karı ve koca, kadın ve erkek, terapist ve hasta, doğa ve kültür, yaşam ve ölüm gibi farklı dikotomik öğeler arasındaki çatışmalar da filmin altyapısından sızan gerçeklikler olarak vurgulanabilir.

Ahlaki sorgulamalar içeren film psikoterapide etik ilkelerin sorgulanabileceği bir zemin yaratmıştır. Bebek kaybı, ölüm, yas, psikolojik sağlı̆̆ın bozulması, şiddet sahneleri gibi içerikler, filmin karamsar bir havaya bürünmesinine neden olmuştur. Bu sebeple filmde ağırlıklı olarak öfke ve üzüntü duygularını işlenmesine neden olmuştur. Bunlara ek olarak film psikolojik açıdan yönetmenin yaşam öyküsü ile ilgili olacak şekilde şekillenmiştir. Yönetmenin annesi ile olan öfkesini kadın karaktere yansıtmak sureti ile başa çıkmaya çalıştığı düşünülmüştür. Yönetmenin baba figürünü ünlü yönetmen Tarkovsky’e yansitarak, onunla özdeşim kurarak ve onu idealize ederek kastrasyon kaygısı ile baş ettiği düşünülmüştür. Ancak, Lars von Trier'in kaygı sorunları olması ve çeşitli fobilere sahip olması kullandığı başetme yönteminin etkili olmadığını gösterir niteliktedir. 


\section{Kaynaklar}

Akbal Süalp, Z. T. (2004). Zaman Mekân Kuram ve Sinema. İstanbul: Bağlam Yayınları Antichrist (n.d.). IMDB sitesinden alınmıştır http://www.imdb.com/title/tt0870984/?ref_=nv_sr_1 http://www.imdb.com/name/nm0001885/bio?ref_=nm_ov_bio_sm

Ainsworth, M. D. (1978). Patterns of Attachment: A Psychological Study of the Strange Situation. Lawrence Erlbaum Associates. ISBN 0-89859-461-8.

Benjamin, W. (2004). Pasajlar (A. Cemal, Çev.) İstanbul: YKY.

Botz-Bornstein, T. (2011). Filmler ve Rüyalar (C. Soydemir, Çev.). İstanbul: Metis.

Bowlby, J. (I980). Attachment and Loss, Vol. 3: Loss, Sadness and Depression. New York: Basic Books.

Bowlby, J. (1988). A Secure Base: Parent-Child Attachment and Healthy Human

Development. New York: Basic Books.

Buck-Morss, S. (2010). Görmenin Diyalektiği. İstanbul: Metis.

Gabbard, G. O. (2004). Long Term Psychodynamic Psychotherapy: A Basic Text.

Washington

DC: American Psychiartic Publishing.

Gençöz, T. (2001). Kaygı bozukluklarının tedavisinde kognitif-yeniden yapılandırma tekniğinin uygulanışı. Kriz Dergisi, 9(2), 23-28.

Harvey, D. (2010). Postmodernliğin Durumu (S. Savran, Çev.). İstanbul: Metis Yayınları. McWilliams, N. (2010) Psikanalitik Tanı (E. Kalem, Çev.). İstanbul: Bilgi Üniversitesi.

Mencütekin, M. (2010). Sinema dili, film retoriği ve imgelenen anlama ulaşma, Öneri Dergisi, 9(34), 259-266.

Paglia, C. (2004). Cinsel Kimlikler (Nefertiti'den Emily Dickinson'a Sanat ve Çöküş) (A. Hazaryan ve D. Atay, Çev.). İstanbul: Epos.

Power M. \& Dalgleish, T. (2008). Cognition and Emotion: From Order to Disorder (2.

Basım) East Sussex: Psychology Press.

Ranciere, J. (2010). Özgürleşen Seyirci (B. Şaman , Çev). İstanbul: Metis.

Stevenson, J. (2005). Lars von Trier (B. Kovulmaz, Çev.). İstanbul: Agora Kitaplığı.

Türk Psikologlar Derneği (2004). Türk Psikologlar Derneği Etik Yönetmeliği. Erişim tarihi 03 Ocak 2014, http://www.psikolog.org.tr/turkey-code-tr.pdf Wolff, W. (1950). Values and Personality: An Existential Psychology of Crisis. New York City, NY, US: Grune \& Stratton. 


\section{Summary \\ The Visual and Psychological Analysis of Lars von Trier's Antichrist Movie}

This article will analyze Lars von Trier's 2009 Antichrist movie. In the scope of this article, after the analysis of the visual characteristics of the movie, the characters, the events and psychological processes of the characters are analyzed. For the visual analysis, it is seen that the movie has an alternative way in cinema arts. Being a four chaptered movie, the story was presented in a progressive manner. The presentation of events which included aggression and atrocity was clearly given. As opposed to the classical cinema work, the attitude which aimed to disturb the audience with excessively realistic expressions was developed by the director. The first characteristic drawing attention in the visuality of the Antichrist movie is the explicit resemblance of the nature scenes to those in the movies of the master director Andrei Tarkovsky. The factors such as the frame defining nature scenes, the selected color, light, shadow, and camera movements in the movie increased the visual quality of the movie. From a psychological point of view, the unresolved problems and stories of the director has a major effect on the movie. Symbolically, ethical inquiries at the therapeutic relation level were presented. Several thriller scenes in the movie were about ethical rules, referring particularly to the multiple relations ethical code. When analyzed in terms of basic emotions, sadness, anger, and fear are the major emotions in the movie in the direction of the content of the scenario.

The fact that Lars von Trier's mother told the truth about Trier's biological father to him immediately before her death, caused the externalization of the Trier's sadness aroused by the loss of a love object and thereby, Trier reflected his anger towards his mother to the female character in the movie. The fact that no negative characteristic was attributed to the father and Trier's presentation of the father in a protective manner may arise from the idealization of Tarkovsky who is a father figure of the director. Via this idealization, the director may seem to overcome the castration anxiety. In addition to those, the movie included many scenes including sexual intercourse of the male and the female characters. However, the director presented these scenes in a way to accuse this sexual relationship for the loss of the child, in a way to show that this sexual relationship was not aimed for the love and satisfaction but for the expression of aggression. This kind of presentation of the sexual relationships is thought to be presented on the basis of Trier's phantasies about the primal scene.

Key words: projection, anger, anxiety, art, defense mechanisms 